\title{
分析化学者のための熱力学と反応速度論 VI
}

\author{
舟橋 重信，田中 元治*
}

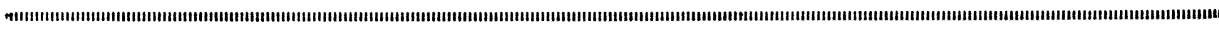

\section{一第 2 部 反応速度論——}

\section{1 反応速度}

\section{1 反応速度式}

化学変化の速さは, 単位時間内に反応物質または生成 物質の濃度がどれだけ変化するかで表わされる。たとえ ば，一般的な反応

$$
\mathrm{aA}+\mathrm{bB} \longrightarrow \mathrm{cC}+\mathrm{dD}
$$

に関しては，反応が始まってから $t$ 時間後の濃度を [A] のように示せば，反応時間 $t$ におけるとの反応速度は

$$
-\frac{\mathrm{d}[\mathrm{A}]}{\mathrm{d} t},-\frac{\mathrm{d}[\mathrm{B}]}{\mathrm{d} t}, \frac{\mathrm{d}[\mathrm{G}]}{\mathrm{d} t} \text { あるいは } \frac{\mathrm{d}[\mathrm{D}]}{\mathrm{d} t}
$$

で表わされる・反応速度と反応物質の濃度との関係を表 わす方程式を反忘速度式 (rate law) という.

今，(1·1) 式で示される反応の速度式が次のようであ るとする。

$$
-\frac{\mathrm{d}[\mathrm{A}]}{\mathrm{d} t}=k[\mathrm{~A}]^{\mathrm{p}}[\mathrm{B}]^{\mathrm{q}}
$$

ここで $k$ はいわゆる速度定数である. 速度式中の各濃 度の指数の和, $\mathrm{p}+\mathrm{q}$ をこの反応の次数といい, $\mathrm{p}$ および qがそれぞれAおよびBに関する次数である.

速度式は反応物質または生成物質の濃度の時間变化を 実験的に測定して決定されなければならないものであっ て，反応の物質収支を示す化学方程式から決定できるも のではない，ある反応機構を仮定すると，それに対する 速度式を数学的に誘導することはできる.しかし異なっ た反応機構の場合でも，同じ形の速度式になる場合もあ る. ある反応機構を仮定し, 誘導した速度式と実験的に 求めた速度式とを比較すれば，考えられるいくつかの反 疬機構のうちで, 正しい反応機構を決定することができ

* 名古屋大学理学部 : 名古屋市千種区不老町
る・実験的に得られた速度式を与える反応機構だけが可 能な反応機構である.

いくつかの連続した反応が起こっている場合，すなわ ち測定している全反応がいくつかの素反応からなってい る場合には，反応速度はそれらの素反応のうちで最もお そい反応によって支配される，その反応の速さを支配し ている段階をその反応の律速段階という。したがって 速度式には律速段階に関与している化学種のみが含まれ る. 律速段階まえの平衡で生じた化学種が律速段階に関 与する場合には，実験的にはとの化学種の濃度は二種以 上の反応物質の濃度の積の形におきかえられて速度式に 含まれてくることになる (1.3 参照).

一つの化学方程式で簡単に表現される反応でも，その 内容が意外に複雑な場合は珍しくない。物質収支を示す 反応方程式は素反応の集合であり，全反応と呼ばれる. もちろん，きわめて簡単な反応では全反応が素反応であ る場合がある. 素反応とは全反応を構成している反応群 の一つであり，それ以上細分化できない最小単位の反応 である・

かりにここで遷移状態の理論の概念に基づいて，その 反応経路のなかにただ一種の活性錯合体しか存在しない ような反応を素反応と定義する・すると活性錯合体を構 成する原系分子の数はいわゆる反応分子数である。した がって素反応を扱うかぎり，反応次数は反応分子数に等 しく，質量作用の法則が成立すると考えられる．逆にい えば，もしもある反応に質量作用の法則が適用できなけ れば，その反応は素反応ではなく，さらに細分化される ものと考えられる.

\section{2 反応次数と速度定数の決定}

反応速度を研究する場合，その反応の速度式を見いだ すことは，研究の大きな部分を占め，反応機構を明らか にするには不可欠なことである。ここで注，実測值から 反応次数や速度定数を決定する方法を比較的簡単な反応 について述べる。しかし複雑な反応に関しても基本的に はなんら変わるところはない。 
今，(1·3) 式で示されるような一種の化学種のみが反

$$
\mathrm{A} \longrightarrow \mathrm{B}
$$

応する場合には，その速度式は一般に次のように表わせ る.Aの減少速度で表わせ汭

$$
-\frac{\mathrm{d}[\mathrm{A}]}{\mathrm{d} t}=k[\mathrm{~A}]^{n}
$$

となり，Bの生成速度で表わせば

$$
\frac{\mathrm{d}[\mathrm{B}]}{\mathrm{d} t}=k\left([\mathrm{~A}]_{0}-[\mathrm{B}]\right)^{n}
$$

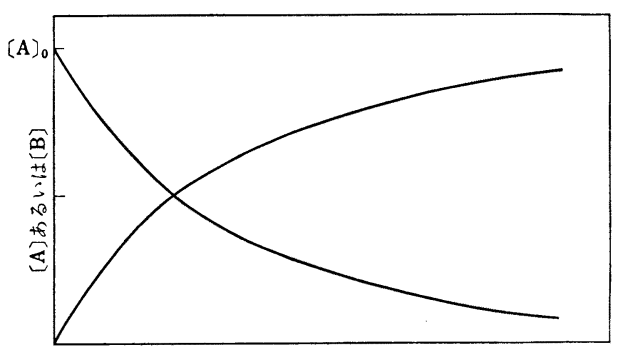

時 間, $t$

困 $1 \cdot 1$ 反応時間 $t$ と反応物質の濃度 [A]あるいは 生成物質の濃度 $[\mathrm{B}]$ との関係

となる。この化学反応の様子を反応物質の濃度あるいは 生成物質の濃度を時間の関数で示すと図 1.1 のように なる.この曲線のある時間における接線の傾きはその時 間での速度である. (1.4)式あるいは(1.5)式の両辺の対 数をとるとそれぞれ

$$
\log \left(-\frac{\mathrm{d}[\mathrm{A}]}{\mathrm{d} t}\right)=\log k+n \log [\mathrm{A}] \quad \cdots(1 \cdot 6)
$$

あるいは

$$
\log \frac{\mathrm{d}[\mathrm{B}]}{\mathrm{d} t}=\log k+n \log \left([\mathrm{A}]_{0}-[\mathrm{B}]\right)
$$

となり，縦軸に $\log (-\mathrm{d}[\mathrm{A}] / \mathrm{d} t)$ を横軸に $\log [\mathrm{A}]$ をと ってプロットすれば，その直線の傾きは $n$ となり，反応 次数 $n$ を決定することができるし, 縦軸の切片から $\log k$ を求めることができる. ある時間における速度 $-\mathrm{d}[\mathrm{A}] / \mathrm{d} t$ を求めるには，数值微分法（Newton の内 そう法など）によるとか, 電子計算機などで求めるとよ い.(1·7) 式に関しても同様である.

また簡単な方法として次のような方法がある. 時間 $t_{1}$ および $t_{2}$ のときの速度がそれぞれ $-\mathrm{d}[\mathrm{A}]_{1} / \mathrm{d} t_{1}$ および $-\mathrm{d}[\mathrm{A}]_{2} / \mathrm{d} t_{2}$ であるならば

$$
\begin{aligned}
& -\frac{\mathrm{d}[\mathrm{A}]_{1}}{\mathrm{~d} t_{1}}=k[\mathrm{~A}]_{1}{ }^{n} \\
& -\frac{\mathrm{d}[\mathrm{A}]_{2}}{\mathrm{~d} t_{2}}=k[\mathrm{~A}]_{2}{ }^{n}
\end{aligned}
$$

となる・したがって

$$
n=\frac{\log \left(\frac{-\frac{\mathrm{d}[\mathrm{A}]_{1}}{\mathrm{~d} t_{1}}}{-\frac{\mathrm{d}[\mathrm{A}]_{2}}{\mathrm{~d} t_{2}}}\right)}{\log \frac{[\mathrm{A}]_{1}}{[\mathrm{~A}]_{2}}}
$$

となり，この式から $n$ を決定することができ，(1·8) 式 および(1.9)式からkを求めることができる.

反応が反応物質 $\mathrm{A}$ に関して一次である場合を考えてみ る. 今, $\mathrm{A}$ の初濃度を $[\mathrm{A}]_{0}$ とし, 時間 $t$ での $\mathrm{A}$ の濃度 を[A]とすると，速度式は

$$
-\frac{\mathrm{d}[\mathrm{A}]}{\mathrm{d} t}=k[\mathrm{~A}]
$$

である. $t=0$ のとき $[\mathrm{A}]=[\mathrm{A}]_{0}$ であるから

$$
\ln \frac{[\mathrm{A}]_{0}}{[\mathrm{~A}]}=2.303 \log \frac{[\mathrm{A}]_{0}}{[\mathrm{~A}]}=k t
$$

となる・したがって， $\ln [\mathrm{A}]_{0} /[\mathrm{A}]$ を $t$ に関してプロッ トすれば，直線の傾きから速度定数を求めることができ る.

2 種類以上の物質が反応に関与している場合には, 他 の成分の濃度を大過剩として*, 反応中に濃度变化がない ようにし，1成分の濃度のみ变化させ，まずその成分に ついての次数をきめ, 次に同じ方法で他の成分について の次数を求めるとよい。こうすれば上に述べた方法を適 用することができる．また，なんらかの方法で $t=0$ の 時の速度, いわゆる初速度が求められるならば, 各濃度 は混合量から容易に求められるから問題注簡単である. たとえば(1.4)式のような速度式の場合には

$$
\text { 初速度 }=\lim _{t \rightarrow 0}\left(-\frac{\mathrm{d}[\mathrm{A}]}{\mathrm{d} t}\right)=k[\mathrm{~A}]_{0}{ }^{n}
$$

となり， $[\mathrm{A}]_{0}$ を変えて初速度と $[\mathrm{A}]_{0}$ との関係から $\mathrm{A}$ に関する次数 $n$ と速度定数 $k$ を求めることができる.

初速度に関連して, もう一つ特別な条件での速度定数 の決定方法を述べる. (1.12) 式は次のように表わすこと ができる。

* 第 2 相中に大過剩の反応物質を存在させ，反応中反 応系中のその反応物質の濃度を一定の低濃度に保つ くふうもされている。 


$$
\begin{aligned}
\frac{[\mathrm{A}]}{[\mathrm{A}]_{0}}= & e^{-k t}=1-k t+\frac{(-k t)^{2}}{2 !}+\cdots \cdots \\
& +\frac{(-k t)^{n}}{n !}+\cdots \cdots
\end{aligned}
$$

ここで, $1 \gg k t$ が成立する反応初期, すなわち $[\mathrm{A}] \simeq$ [A] 0 の時には，(114)式の第 3 項以下は無視できるの で

$$
[\mathrm{A}]=\left[\mathrm{A}_{0}\right](1-k t)
$$

となり，[A]と $t$ とは直線関係にあるから，その直線の 傾きから $k$ を求めることができる.

反応物質の濃度が半分に減少する時間を半減期とい う. 一般に $n$ 次反応では $-\mathrm{d}[\mathrm{A}] / \mathrm{d} t=k[\mathrm{~A}]^{n}$ であるか ら, $n \neq 1$ の場合に注半減期 $t_{1 / 2}$ は

$$
t_{1 / 2}=\frac{[\mathrm{A}]_{0}^{1-n}}{k(1-n)}\left(1-\frac{1}{2^{1-n}}\right)
$$

となる. したがって, $\log t_{1 / 2}$ と $\log [\mathrm{A}]_{0}$ のプロット は直線となり，その直線の傾きから $n$ を決定することが できる。また反応が一次反応の場合には, 半減期は（1・ 17）式のようになる.

$$
t_{1 / 2}=\frac{1}{k} \ln 2=\frac{0.693}{k}
$$

したがって，この場合には半減期は反応物質の初濃度 飞無関係で, 速度定数の值の逆数に比例する関係にな り，kを決定することができる。

次に 2 次反応

$$
2 \mathrm{~A} \longrightarrow \mathrm{P}+\cdots \cdots
$$

の場合を考える. 反応開始後 $t$ 時間後に A の濃度が [A] のとき, 速度式は

$$
-\frac{\mathrm{d}[\mathrm{A}]}{\mathrm{d} t}=k[\mathrm{~A}]^{2}
$$

となり，これを解くと，t=0 のとき $[\mathrm{A}]=[\mathrm{A}]_{0}$ である から

$$
\frac{1}{[\mathrm{~A}]}=\frac{1}{[\mathrm{~A}]_{0}}+k t
$$

となり，1/[A]の $t$ に対するプロットは直線となり，そ の傾きから $k$ を求めることができる.

また次のような 2 次反応

$$
\mathrm{A}+\mathrm{B} \longrightarrow \mathrm{P}+\cdots \cdot
$$

の場合には，反応開始 $t$ 時間後にAの濃度が[A]である とすると, 速度式は

$$
-\frac{\mathrm{d}[\mathrm{A}]}{\mathrm{d} t}=k[\mathrm{~A}][\mathrm{B}]=k[\mathrm{~A}]\left([\mathrm{B}]_{0}-[\mathrm{A}]_{0}+[\mathrm{A}]\right)
$$

となる. $t=0$ のときは $[\mathrm{A}]=[\mathrm{A}]_{0}$ であるから，これを 解くと

$$
\begin{aligned}
& \frac{1}{[\mathrm{~B}]_{0}-[\mathrm{A}]_{0}} \ln \frac{[\mathrm{A}]_{0}\left([\mathrm{~B}]_{0}-[\mathrm{A}]_{0}+[\mathrm{A}]\right)}{[\mathrm{B}]_{0}[\mathrm{~A}]} \\
& =k t
\end{aligned}
$$

となる・ただし $\mathrm{A} と \mathrm{~B}$ の初濃度， $[\mathrm{A}]_{0}$ と $[\mathrm{B}]_{0}$ 法等し くないとする.したがって, $\log \left\{\left([\mathrm{B}]_{0}-[\mathrm{A}]_{0}+[\mathrm{A}]\right) /\right.$ $[\mathrm{A}]\}$ と $t$ とのプロットで得られる直線の傾きから $k$ を 求めることができる.

上記のような積分式 $\{(1 \cdot 12)$ 式，(1·20)式あるいは， (1·23) 式\}に従ってプロットして, 直線性があるから, 1 次反応であるとか，2 次反応であるとかを決定してい る論交が多くある.しかし次のような場合があるから， その直線性はじゅうぶんであるかどうか注意する必要が ある、今，(1.12)式のように表わされる 1 次反応である ベきデータを(1.20)式のような 2 次反応速度式の積分式 に従ってプロットしたのが図 1.2 である. 図 1.2 から

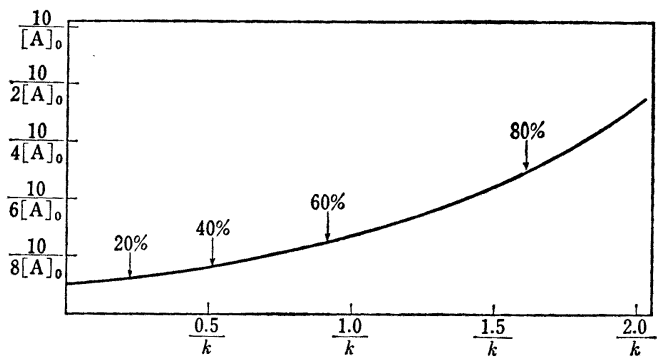

図1.2（1.12)式に従うデータを(1.20)式でプロッ トした場合のグラフ

わかるように，1 次反応であるべきデータを 2 次反応 として取り扱っても，反応が $50 \%$ ぐらいのところまで は, 割合直線性がある。このように，化学量論的に考え ると 2 次反応でありうるが，実際は 1 次反応である場合 にまちがった結論を下すおそれがあるから気をつけなけ ればならない。このような例は，金属イオンが配位子と 反応して，1:2 錯体をつくる反応の場合である：この 種の錯形成の反応速度は, 一つ目の配位子が配位し, 1 : 1 錯体をつくる段階が律速段階で二つ目の配位子が結合 する反応注速いのが普通である。したがってこのような 反応は配位子に関して1次である.たとえば $\mathrm{Co}^{2+}, \mathrm{Ni}^{2+}$, 
$\mathrm{Zn}^{2+}$ などの重金属イオンと $2,2^{\prime}$-ビピリジン, 1,10 - フ エナントロリン，4-(2-ピリジルアゾ)ーレゾルシンなど の錯形成反応は配位子に関して1 次反応である122). この ようなわけで，乙の種のプロットは少なく之も $80 \% く ゙$ らいまでのデータで判断すべきであり，他の解析方法を も併用し検討することが必要である。

次のような反応を吸光光度法*で測定した場合に，そ の反応次数と初速度を決定する1例を示すことにする.

$$
\mathrm{aA}+\mathrm{bB} \longrightarrow \mathrm{cC}+\mathrm{dD}
$$

(1·24) 式に従う反応において, Aの濃度に比べて Bの 濃度が大過剩存在 $\left\{(\mathrm{a} / \mathrm{b})[\mathrm{A}]_{0} \ll[\mathrm{B}]_{0}\right\}$ し, 反応が定量 的に右に進行する場合を考える. 反応開始 $t$ 時間後にA が $x$ だけ反応したときの吸光度を $E_{\mathrm{t}}$, 反応以前および 反応完了後の吸光度をそれぞれ $E_{0}, E_{\infty}$ とすると次の ような関係が成立する。

$$
\begin{aligned}
E_{0}= & {[\mathrm{A}]_{0} \varepsilon_{\mathrm{A}}+[\mathrm{B}]_{0} \varepsilon_{\mathrm{B}} } \\
E_{\mathrm{t}}= & \left([\mathrm{A}]_{0}-x\right) \varepsilon_{\mathrm{A}}+\left([\mathrm{B}]_{0}-\frac{\mathrm{b}}{\mathrm{a}} x\right) \varepsilon_{\mathrm{B}} \\
& +\frac{\mathrm{c}}{\mathrm{a}} x \varepsilon_{\mathrm{C}}+\frac{\mathrm{d}}{\mathrm{a}} x \varepsilon_{\mathrm{D}} \\
E_{\infty}= & \left([\mathrm{B}]_{0}-\frac{\mathrm{b}}{\mathrm{a}}[\mathrm{A}]_{0}\right) \varepsilon_{\mathrm{B}}+\frac{\mathrm{c}}{\mathrm{a}}[\mathrm{A}]_{0} \varepsilon_{\mathrm{C}}+\frac{\mathrm{d}}{\mathrm{a}}[\mathrm{A}]_{0} \varepsilon_{\mathrm{D}}
\end{aligned}
$$

ここで はモル吸光係数である. (1·25) 式，(1·26)式 および(1.27)式から

$$
\frac{x}{[\mathrm{~A}]_{0}}=\frac{E_{\mathrm{t}}-E_{0}}{E_{\infty}-E_{0}}
$$

となる・（1·24）式に対する速度式は次のように表わせ る.

$$
\frac{\mathrm{d} x}{\mathrm{~d} t}=k\left([\mathrm{~A}]_{0}-x\right) \mathrm{p}\left([\mathrm{B}]_{0}-\frac{\mathrm{b}}{\mathrm{a}} x\right)^{\mathrm{q}}
$$

条件として $[\mathrm{B}]_{0} \gg(\mathrm{b} / \mathrm{a})[\mathrm{A}]_{0}$ であるから

$$
\frac{\mathrm{d} x}{\mathrm{~d} t}=k_{(\mathrm{B})}\left([\mathrm{A}]_{0}-x\right)^{\mathrm{p}}
$$

と書き替えることができる．ここで $k_{(\mathrm{B})}=k[\mathrm{~B}]_{0} \mathrm{q}$ で， $k_{(\mathrm{B})}$ は $\mathrm{B}$ の濃度を含丢条件反応速度定数**である.（1. 28)式を(1·30)式に代入すると

* 吸光度でなくとも, 測定される物性（旋光度, 電導 度など）が物質の濃度と比例するものであればまっ たく同じように取り报うことができる.

** その定数に濃度や平衡定数などが含まれており, そ の実験条件では定数であるような反応速度定数を条 件反応速度定数と呼ぶ.

$$
\begin{aligned}
\frac{\mathrm{d} x}{\mathrm{~d} t} & =\frac{\mathrm{d}\left([\mathrm{A}]_{0} \frac{E_{\mathrm{t}}-E_{0}}{E_{\infty}-E_{0}}\right)}{\mathrm{d} t}=k_{(\mathrm{B})}\left([\mathrm{A}]_{0}-[\mathrm{A}]_{0} \frac{E_{\mathrm{t}}-E_{0}}{E_{\infty}-E_{0}}\right)^{\mathrm{p}} \\
& =\frac{[\mathrm{A}]_{0}}{E_{\infty}-E_{0}} \frac{\mathrm{d}\left(E_{\mathrm{t}}-E_{0}\right)}{\mathrm{d} t}=k_{(\mathrm{B})}\left([\ddot{\mathrm{A}}]_{0} \frac{E_{\infty}-E_{\mathrm{t}}}{E_{\infty}-E_{0}}\right)^{\mathrm{p}}
\end{aligned}
$$

すなわち

$$
\frac{\mathrm{d}\left(E_{\mathrm{t}}-E_{0}\right)}{\mathrm{d} t}=k_{(\mathrm{B})}\left(\frac{[\mathrm{A}]_{0}}{E_{\infty}-E_{0}}\right)^{\mathrm{p}-1}\left(E_{\infty}-E_{\mathrm{t}}\right)^{\mathrm{p}}
$$

となる. (1-32) 式の両辺の対数をとれば（ $E_{\mathrm{t}}>E_{0}$ とす る)

$$
\begin{gathered}
\log \left(\frac{\mathrm{d}\left(E_{\mathrm{t}}-E_{0}\right)}{\mathrm{d} t}\right)=\log k_{(\mathrm{B})}+(\mathrm{p}-1) \log \frac{[\mathrm{A}]_{0}}{E_{\infty}-E_{0}} \\
+\mathrm{p} \log \left(E_{\infty}-E_{\mathrm{t}}\right) \quad \cdots \cdots \cdots \cdots \cdots \cdots \cdots \cdots \cdots \cdots \cdots \cdots \cdots \cdots \cdots(1 \cdot 33)
\end{gathered}
$$

となり, $\log \left\{\mathrm{d}\left(E_{\mathrm{t}}-E_{0}\right) / \mathrm{d} t\right\}$ と $\log \left(E_{\infty}-E_{\mathrm{t}}\right)$ と穵プロ

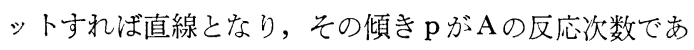
る. 一方, この直線から $t=0$ の時の速度, いわゆる初 速度 $\left\{\mathrm{d}\left(E_{\mathrm{t}}-E_{0}\right) / \mathrm{d} t\right\}_{t=0}$ を求めることができる. また $(1 \cdot 31)$ 式から，t=0 の時

$$
\begin{aligned}
&\left(\frac{\mathrm{d} x}{\mathrm{~d} t}\right)_{t=0}=\frac{[\mathrm{A}]_{0}}{E_{\infty}-E_{0}}\left(\frac{\mathrm{d}\left(E_{\mathrm{t}}-E_{0}\right)}{\mathrm{d} t}\right)_{t=0} \\
&=k_{(\mathrm{B})}[\mathrm{A}]_{0} \mathrm{p} \\
& \ldots \ldots \ldots \ldots \ldots \cdots \cdots
\end{aligned}
$$

となり， $k_{(\mathrm{B})}$ の值を知ることができる． [B]。変化さ せて $k_{(\mathrm{B})}$ を $[\mathrm{B}]_{0}$ の関数として求めれば $k_{(\mathrm{B})}=k[\mathrm{~B}]_{0}{ }^{9}$ であるから， $\log k_{(\mathrm{B})}$ と $\log [\mathrm{B}]_{0}$ に対するグラフは 直線となり切片から $k$ が得られ，傾きから $\mathrm{B}$ に関する反 応次数 qがわかる.

\section{3 $\mathrm{A} \rightleftarrows \mathbf{B} \rightleftarrows \mathbf{C}$ の反応速度}

次のような反応はいろいろな反応系でしばしば見受け られる。

$$
\mathrm{A} \underset{k_{2}}{\stackrel{k_{1}}{\rightleftarrows}} \mathrm{B} \underset{k_{4}}{\stackrel{k_{3}}{\rightleftarrows}} \mathrm{C}
$$

さらに反応経路が多くなっても，基本的には同じよう な数式の取り扱いによって速度式を導くことができる. また速度定数 $k$ の大小関係を考慮すれば，二，三の別の 反応系にも適用できるので，(1·35)式で示される反応を 一般的に取り扱うことにする.

今, $\mathrm{A}$ の初濃度に対する反応時間 $t$ での $\mathrm{A}, \mathrm{B}, \mathrm{C}$ の 濃度の比をそれぞれ $x, y, z\left([\mathrm{~A}] /[\mathrm{A}]_{0}=x,[\mathrm{~B}] /[\mathrm{A}]_{0}\right.$ $\left.=y,[\mathrm{C}] /[\mathrm{A}]_{0}=z\right)$ とすると

$$
x+y+z=1
$$


各化学種に関する反応速度式は

$$
\begin{aligned}
& \frac{\mathrm{d} x}{\mathrm{~d} t}=-k_{1} x+k_{2} y \\
& \frac{\mathrm{d} y}{\mathrm{~d} t}=k_{1} x-k_{2} y-k_{3} y+k_{4} z \\
& \frac{\mathrm{d} z}{\mathrm{~d} t}=k_{3} y-k_{4} z
\end{aligned}
$$

となる・(1·37)式を $t$ に関して微分すると

$$
\frac{\mathrm{d}^{2} x}{\mathrm{~d} t^{2}}=-k_{1} \frac{\mathrm{d} x}{\mathrm{~d} t}+k_{2} \frac{\mathrm{d} y}{\mathrm{~d} t}
$$

$(1 \cdot 40)$ 式に $(1 \cdot 38)$ 式と $(1 \cdot 36)$ 式を代大すると

$$
\frac{\mathrm{d}^{2} x}{\mathrm{~d} t^{2}}=-k_{1} \frac{\mathrm{d} x}{\mathrm{~d} t}+k_{2}\left\{\left(k_{1}-k_{4}\right) x-\left(k_{2}+k_{3}+k_{4}\right) y+k_{4}\right\}
$$

さらに(1·37)式を使って $y$ を消去すると， $x$ だけの関 数として次の式を得る.

$$
\begin{aligned}
\frac{\mathrm{d}^{2} x}{\mathrm{~d} t^{2}} & +\left(k_{1}+k_{2}+k_{3}+k_{4}\right) \frac{\mathrm{d} x}{\mathrm{~d} t} \\
& +\left(k_{1} k_{3}+k_{2} k_{4}+k_{1} k_{4}\right) x=k_{2} k_{4}
\end{aligned}
$$

ここで式の取り扱いを簡単にするため

$$
\begin{aligned}
& k_{1}+k_{2}+k_{3}+k_{4}=2 \alpha \\
& k_{1} k_{3}+k_{2} k_{4}+k_{1} k_{4}=\beta
\end{aligned}
$$

とおくと

$$
\frac{\mathrm{d}^{2} x}{\mathrm{~d} t^{2}}+2 \alpha \frac{\mathrm{d} x}{\mathrm{~d} t}+\beta x=k_{2} k_{4}
$$

となる・(1.45)式は定数係数である線型微分方程式であ る.この方程式の根は

$$
\begin{aligned}
& r_{1}=-\alpha+\sqrt{\alpha^{2}-\beta} \\
& r_{2}=-\alpha-\sqrt{\alpha^{2}-\beta}
\end{aligned}
$$

であるから，一般解は

$$
x=c_{1} e^{r_{1} t}+c_{2} e^{r_{2} t}+\frac{k_{2} k_{4}}{\beta}
$$

である. $t=0$ のとき $x=1, \mathrm{~d} x / \mathrm{d} t=-k_{1}$ 「であるから， それらを用いて定数 $c_{1}, c_{2}$ を求めると

$$
\begin{aligned}
& c_{1}=\frac{\beta k_{1}+r_{2}\left(\beta-k_{2} k_{4}\right)}{\left(r_{2}-r_{1}\right) \beta} \\
& c_{2}=\frac{\beta k_{1}+r_{1}\left(\beta-k_{2} k_{4}\right)}{\left(r_{1}-r_{2}\right) \beta}
\end{aligned}
$$

また $z$ に関しても $x$ の場合と同様にして次の関係式を 導くことができる。

$$
\begin{aligned}
z & =c_{3} e^{r_{1} t}+c_{4} e^{r_{2} t}+\frac{k_{1} k_{3}}{\beta} \\
c_{3} & =\frac{r_{2} k_{1} k_{3}}{\left(r_{1}-r_{2}\right) \beta} \quad \ldots \ldots . . . \\
c_{4} & =\frac{r_{1} k_{1} k_{3}}{\left(r_{2}-r_{1}\right) \beta} \quad \ldots \ldots . . .
\end{aligned}
$$

yに関しては

$$
y=1-x-z
$$

である・

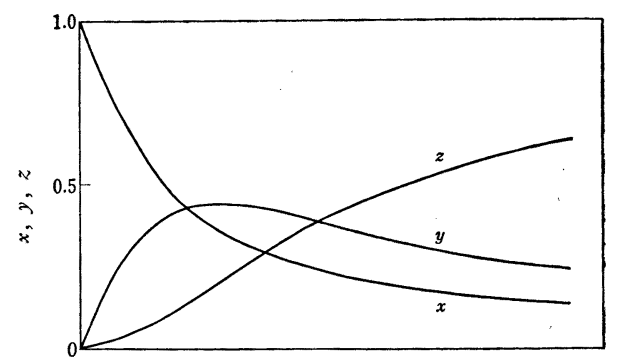

反応時間, $t$

図 1.3 反応式(1.35)における各化学種の濃度の時 間变化

図 1.3 には反応式 $(1 \cdot 35)$ に従う反応における各化学 種の濃度と反応時間との関係の概略が示してある.この 曲線で $t \rightarrow \infty$ における $x, y, z$ の值は

$$
\begin{aligned}
& \lim _{t \rightarrow \infty} x=\frac{k_{2} k_{4}}{k_{1} k_{3}+k_{2} k_{4}+k_{1} k_{4}}=\frac{1}{1+\frac{k_{1}}{k_{2}}+\frac{k_{1}}{k_{2}} \frac{k_{3}}{k_{4}}} \\
& \lim _{t \rightarrow \infty} y=\frac{1}{1+\frac{k_{2}}{k_{1}}+\frac{k_{3}}{k_{4}}} \\
& \lim _{t \rightarrow \infty} z=\frac{1}{1+\frac{k_{4}}{k_{3}}+\frac{k_{2}}{k_{1}} \frac{k_{4}}{k_{3}}}
\end{aligned}
$$

また， $t \rightarrow \infty$ の時の $y, z$ を $x$ で表わせば，平衡関係 から導かれるように

$$
\left.\begin{array}{l}
\lim _{t \rightarrow \infty} \frac{y}{x}=\frac{k_{1}}{k_{2}} \\
\lim _{t \rightarrow \infty} \frac{z}{x}=\frac{k_{1}}{k_{2}} \frac{k_{3}}{k_{4}}
\end{array}\right\}
$$

となる・

以上は反応式(1.35)で示される反応に関して, 一般的 に取り扱った. 速度定数 $k_{1}, k_{2}, k_{3}, k_{4}$ の大小関係を考 慮すれば，いろいろな反応型の速度式をこれらの一般式 から導くことができる。 
たとえば， $k_{1}+k_{2} \gg k_{3} \gg k_{4}$ のような場合，すなわち， $\mathrm{A} \rightleftarrows \mathrm{B}$ の平衡がすみやかに成立し， $k_{3}$ に律速されて反 応が進行する場合を考えてみると，(1.46)式と(1.47)式 の $r_{1}$ と $r_{2}$ は

$$
\begin{aligned}
& r_{1}=-\frac{k_{1} k_{3}}{k_{1}+k_{2}} \\
& r_{2}=-\left(k_{1}+k_{2}\right)
\end{aligned}
$$

となり，x近似的に

$$
\begin{aligned}
x= & \frac{k_{2}}{k_{1}+k_{2}} e^{-\frac{k_{1}}{k_{1}+k_{2}} k_{3} t} \\
& +\frac{k_{1}}{k_{1}+k_{2}} e^{-\left(k_{1}+k_{2}\right) t}
\end{aligned}
$$

となる. $k_{1}+k_{2} \gg k_{3}$ であるから, 右辺の第 2 項は第 1 項 に比べ急速に 0 に近づき, 反応の初期を除けば第 2 項は 無視することができる・したがって

$$
\cdot x=\frac{k_{2}}{k_{1}+k_{2}} e^{-\frac{k_{1}}{k_{1}+k_{2}} k_{3} t}
$$

同じようにして $y$ と $z$ は

$$
\begin{aligned}
& y=\frac{k_{1}}{k_{1}+k_{2}} e^{-\frac{k_{1}}{k_{1}+k_{2}} k_{3} t} \\
& z=1-e^{-\frac{k_{1}}{k_{1}+k_{2}}} \ldots \ldots \ldots \ldots
\end{aligned}
$$

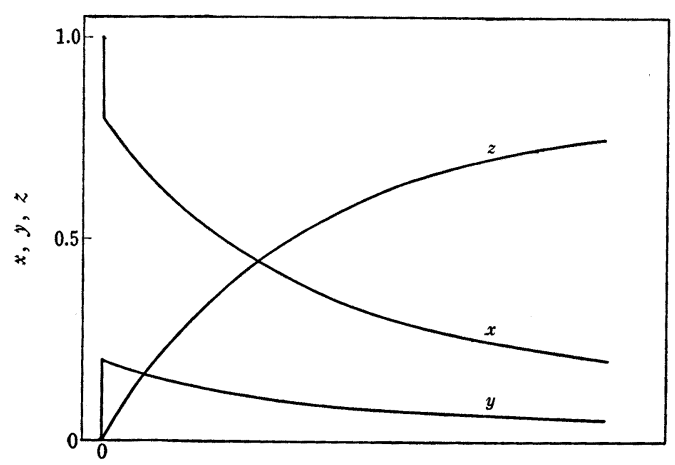

反応時間, $t$

図 1.4 反応式(1.35)において, $k_{1}+k_{2} \gg k_{3} \gg k_{4}$ の 場合における各化学種と反応時間との関係

となる.ここで $x$ と $y$ の比は $x: y=k_{2}: k_{1}$ となり, A と $\mathrm{B}$ との間に平衡が成立していることがわかる．この間 の様子を図 1.4 に示してある. すなわち反応開始直後 飞平衡 $\mathrm{A} \rightleftarrows \mathrm{B}$ が成立し, 以後 $\mathrm{C}$ の生成につれ減少する
Bをすみやかに補いつつ，したがって部分平衡の関係 $\left(x / y=k_{2} / k_{1}\right)$ が保たれながら反応が進行している.

また $\mathrm{B}$ の平衡濃度が非常に小さい場合，すなわち $k_{1} \ll$ $k_{2}$ の場合には (1.58) 式と (1.60) 式から

$$
\begin{aligned}
& x=e^{-K_{12} k_{3} t} \\
& z=1-e^{-K_{12} k_{3} t}
\end{aligned}
$$

となる.ここで $K_{12}=k_{1} / k_{2}$ である.

次に(1·35)式で示される反応系で $k_{2}+k_{3} \gg k_{1} \gg k_{4} \simeq 0$ のような条件の場合を考えてみる。こ机は Bの濃度は $\mathrm{A}$ や $\mathrm{C}$ の濃度に比べじゅうぶえ小さいことを意味してい る.この条件では

$$
\sqrt{\alpha^{2}-\beta}=\frac{k_{2}+k_{3}}{2}
$$

と近似できるので $(1.46)$ 式と $(1.47)$ 式の $r_{1}$ と $r_{2}$ と を近似計算すると

$$
\begin{aligned}
& r_{1}=-\frac{k_{1} k_{3}}{k_{2}+k_{3}} \\
& r_{2}=-\left(k_{2}+k_{3}\right)
\end{aligned}
$$

となり, $\left|r_{1}\right| \ll\left|r_{2}\right|$ である. 今, $k_{4} \simeq 0$ であるから (1.48) 式と (1.54) 式の $x$ と $y$ は

$$
\begin{aligned}
& x=-\frac{k_{1}+r_{2}}{r_{1}-r_{2}} e^{r_{1} t}+\frac{k_{1}+r_{1}}{r_{1}-r_{2}} e^{r_{2}} t \\
& y=\frac{k_{1}}{r_{1}-r_{2}}\left(e^{r_{1} t}-e^{r_{2} t}\right)
\end{aligned}
$$

となる・したがって $e^{r_{2} t}$ を含む (1.63) および(1.64)式 の第 2 項が無視できる場合には

$$
\begin{aligned}
& x=e^{-\frac{k_{1} k_{3}}{k_{2}+k_{3}} t} \ldots \ldots \\
& y=\frac{k_{1}}{k_{2}+k_{3}} e^{-\frac{k_{1}}{k_{2}+k_{3}}}
\end{aligned}
$$

となる・このような場合，すなわち $\mathrm{B} か ゙$ 非常に反応性に

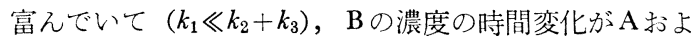
びCの濃度の時間変化に比べて非常に少さい場合, いい かえればBの反応速度 $\mathrm{d} y / \mathrm{d} t$ が事実上ゼロとみなすこ とができる場合を Bに関して定常状態であるという．こ のように B について定常状態が成立する場合の反応物 質, 生成物質の時間変化を図 1.5 に示す. これは $k_{2}=$ $k_{3}=100 k_{1}$ の場合で, $t \geqq 4 /\left(k_{2}+k_{3}\right)$ では(1.64) 式におい て Bの存在量の $2 \%$ 以内の誤差で定常状態が成立して いる. 一般に $k_{2}+k_{3}=n k_{1}$ の場合， $t \geqq 4 / n k_{1}$ ならば $\mathrm{B} の$ 存在量の $2 \%$ 以内の誤差で定常状態が成立する.すな 


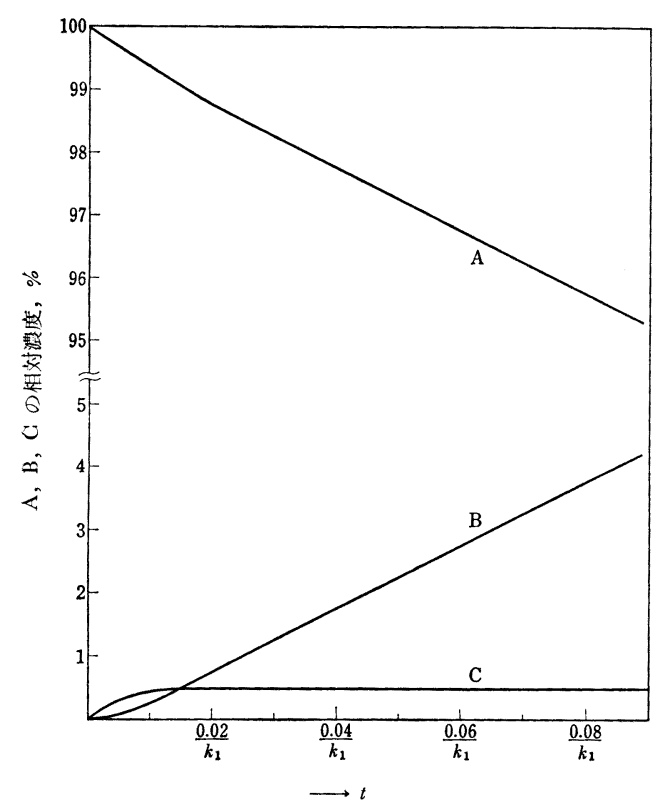

図 1.5 反応式(1.35)において B について定常状態 が成立する場合の A, B , C の濃度変化 $100 k_{1}=k_{2}=k_{3}$ : Aの反応量が $1.3 \%$ 程度である $t=0.02$ / $k_{1}$ でほぼ定常状態が成立している.

わち $n$ が大きいほど反応初期から定常状態が成立する.

以上のような関係式はいわゆる定常状態を仮定して行 なう近似計算によっても導くことができる． $k_{4}$ が無視 できるとすれば

$$
\frac{\mathrm{d} y}{\mathrm{~d} t}=k_{1} x-k_{2} y-k_{3} y
$$

となる・ここで $\mathrm{B}$ に関して定常状態を仮定すれば $\mathrm{d} y / \mathrm{d} t$ $=0$ と考えてよいから，Bの定常状態における濃度は

$$
y=\frac{k_{1}}{k_{2}+k_{3}} x
$$

となる・一方

$$
-\frac{\mathrm{d} x}{\mathrm{~d} t}=k_{1} x-k_{2} y=\frac{k_{1} k_{3}}{k_{2}+k_{3}} x
$$

したがって

$$
x=e^{-\frac{k_{1} k_{3}}{k_{2}+k_{3}} t}
$$

そなり，この式はさきの (1.65) 式と一致する.(1.67)式 を時間について微分すれば

$$
\frac{\mathrm{d} y}{\mathrm{~d} x}=\frac{k_{1}}{k_{2}+k_{3}} \frac{\mathrm{d} x}{\mathrm{~d} t}
$$

となる・ここで $k_{1} \ll k_{2}+k_{3}$ であるから

$$
\frac{\mathrm{d} y}{\mathrm{~d} t} \ll \frac{\mathrm{d} x}{\mathrm{~d} t}
$$

となり, $\mathrm{A} の$ 変化量に比べて $\mathrm{B}$ の変化量はきわめて小さ く, 定常状態の仮定は $k_{1}$ が $k_{2}+k_{3}$ に比べて小さけれ ば小さいほどよくなりたつことがわかる. 定常状態では $\mathrm{d} y / \mathrm{d} t=0$ であるからBの濃度は一定であるというよう に考えるの注誤りで $-d y / d t$ が $-d x / d t$ や $\mathrm{d} z / \mathrm{d} t$ に比 ベてきわめて小さいということにすぎない.とのことは (1-67)式において $x$ は $y$ に比例していることからもわか る.

(1.58) 式, (1.61) 式それに(1.65) 式は 1 次反応の形を している.このように 1 次反応形でそのる，速度定数に 注数種の速度定数や平衡定数が含まれる場合があること は注意すべきことである。

次のような反応機構の反応速度式を考える。

$$
\begin{aligned}
& \mathrm{A}+\mathrm{B} \underset{k_{2}}{\stackrel{k_{1}}{\rightleftarrows}} \mathrm{C} \\
& \mathrm{C}+\mathrm{D} \stackrel{k_{3}}{\longrightarrow} \mathrm{E}
\end{aligned}
$$

Gの生成速度は

$$
\frac{\mathrm{d}[\mathrm{C}]}{\mathrm{d} t}=k_{1}[\mathrm{~A}][\mathrm{B}]-k_{2}[\mathrm{C}]-k_{3}[\mathrm{C}][\mathrm{D}]
$$

である、中間生成物 Cが非常に反応しやすい場合には， G に関して定常状態法を適用すると Cの定常状態におけ る濃度は

$$
[\mathrm{C}]=\frac{k_{1}[\mathrm{~A}][\mathrm{B}]}{k_{2}+k_{3}[\mathrm{D}]}
$$

である・ゆえに $\mathrm{E} の$ 生成速度は次の速度式によって与え られる・

$$
\frac{\mathrm{d}[\mathrm{E}]}{\mathrm{d} t}=k_{3}[\mathrm{C}][\mathrm{D}]=\frac{k_{1} k_{3}[\mathrm{~A}][\mathrm{B}][\mathrm{D}]}{k_{2}+k_{3}[\mathrm{D}]}
$$

$k_{2} \gg k_{3}[\mathrm{D}]$ の場合には(1.72)式は

$$
\frac{\mathrm{d}[\mathrm{E}]}{\mathrm{d} t}=\frac{k_{1} k_{3}}{k_{2}}[\mathrm{~A}][\mathrm{B}][\mathrm{D}]
$$

となる、この条件のもとでは，Dの濃度に依存する 3 次 反応である.

$k_{3}[\mathrm{D}] \gg k_{2}$ の条件のもとでは，(1.72)式は

$$
\frac{\mathrm{d}[\mathrm{E}]}{\mathrm{d} t}=k_{1}[\mathrm{~A}][\mathrm{B}]
$$


となり，Dの濃度に依存しない 2 次反応である.

このように濃度関係によっても速度式が異なる場合が あるからできるだけ広範囲の濃度で検討することが必要 である.そうすることによって，反応機構をより完全に 知る手がかりともなる。また既知の反応速度式を利用す る場合も，条件が变われば速度式が違ってくる場合があ るから，じらぶん注意する必要がある。

定常状態の例として最近研究された次のようなキレー

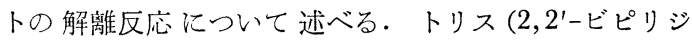
ン)ーバナジウム (II) $\left\{\mathrm{V}\right.$ (bipy) $\left.{ }_{3}{ }^{2+}\right\}$ の解離反応速度はト

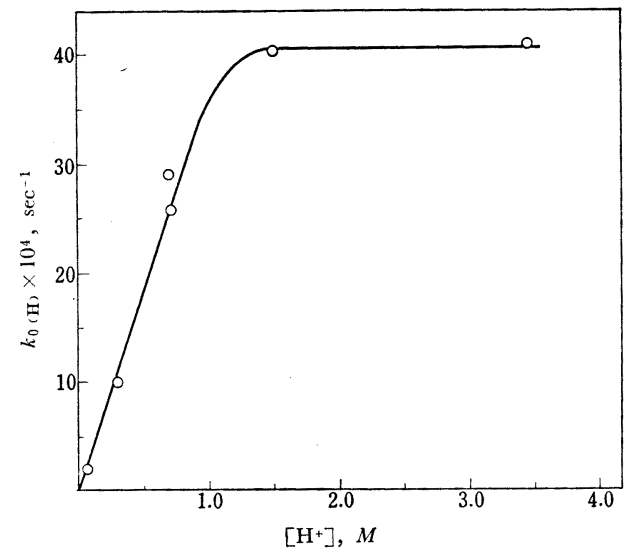

図 1.6 速度定数と酸濃度との関係<smiles></smiles><smiles>c1ccc(-c2ccccn2)nc1</smiles>
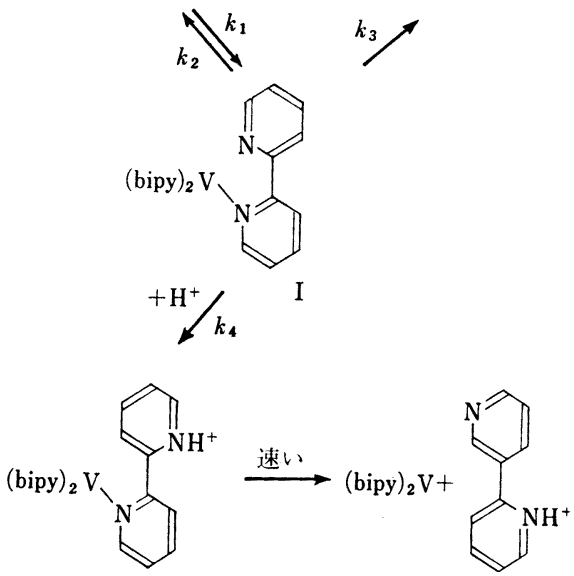

四 1.7 トリス $\left(2,2^{\prime}\right.$-ビピリジン)ーバナジウム (II) 錯体 $\left\{\mathrm{V}\right.$ (bipy) $\left.{ }_{3}{ }^{2+}\right\}$ の解離反応機構
リス $\left(2,2^{\prime}\right.$-ビピリジン)ーバナジウム (II) 錯体溶液に硫酸 を加えることによって研究された ${ }^{3)}$ ，速度定数と酸濃度 との関係は図 1.6 のような結果が得られている。この 結果から解離反応は図 1.7 に示したような機構である ことが推定される。すなわち，図 1.7 ののようなバ ナジウムとビピリジンとの結合の一つが切れた中間体が 定常状態にあると考えられ，測定された条件速度定数 $k_{0}(\mathrm{H})$ は

$$
k_{0(\mathrm{H})}=k_{1}\left(\frac{k_{3}+k_{4}\left[\mathrm{H}^{+}\right]}{k_{2}+k_{3}+k_{4}\left[\mathrm{H}^{+}\right]}\right)
$$

となる、酸濃度が大きい場合, 寸なわち $k_{2}+k_{3} \ll k_{4}\left[\mathrm{H}^{+}\right]$ の場合には， $k_{0(\mathrm{H})}=k_{1}=4.0 \times 10^{-3} \mathrm{sec}^{-1}\left(25^{\circ} \mathrm{C}\right)$ とな り，酸濃度に依存せず，ビピリジンの 1 個のNがバナジ ウムから解離する段階が律速段階である。酸濃度が低い 条件で江 $k_{0}(\mathrm{H})=k_{1} k_{3} /\left(k_{2}+k_{3}\right) \leq 2 \times 10^{-5} \sec ^{-1}\left(25^{\circ} \mathrm{C}\right)$ と なる。このように実験条件が変わ机汭反応経路も律速段 階も変わる.バナジウム (II) 到 $d^{3}$ で反応がおそいことが 期待されるが，この反応も半減期が数時間でおそい反応 である.この種の解離反応については, 分析化学的にも興 味ある第一遷移金属と 1,10-フェナントロリンや 2,2'ビピリジとの錯体に関して多く研究されている4～

\section{2 反応速度論}

\subsection{Arrhenius の式と衝突活性説}

反応温度が高ければ，それだけ反応速度は大きくな る。これは Svante Arrhenius (1859〜1927) が一般的 な意義をはじめて認識し

$$
\frac{\mathrm{d} \ln k}{\mathrm{~d} T}=\frac{E_{\mathrm{a}}}{R T^{2}}
$$

で表わせることを提案した。ここで $T$ は絶対温度 ${ }^{\circ} \mathrm{K}$ ， $E_{\mathrm{a}}$ 汇活性化エネルギーである.この式が一般に Arrhenius の式と呼ばれる. Arrhenius はさらに $E_{\mathrm{a}}$ は定数で ある（あとで指摘するようにこれは近似的にしか正しく ない）と仮定し，(2・1)式を積分して速度定数の温度変 化を

$$
k=\mathrm{A} e^{-E \mathrm{a} / R T}
$$

という形の式で表わした.

気体分子運動論からも同じ形の式を誘導することがで きる.すなわち，二つの分子が衝突した瞬間において， 分子の中心を結ぶ方向への全進運動エネルギーの成分が 活性化エネルギー $E_{\mathrm{a}}$ をこえるときにのみ反応が起こ り，それが $E_{\mathrm{a}}$ より小さけれ机反応は起こらないと考え られた・これが衝突活性説である。 
気体分子運動論によって気体分子の持つエネルギーの 分布や単位時間内に衝突する分子の数を計算することが できる.それを用いて速度定数 $k$ を求めると

$$
\begin{aligned}
& k=\mathrm{p} Z e^{-E \mathrm{a} / R T} \\
& Z=\frac{N}{1000}\left(\frac{\sigma_{1}+\sigma_{2}}{2}\right)^{2} \sqrt{8 \pi R T\left(\frac{1}{M_{1}}+\frac{1}{M_{2}}\right)}
\end{aligned}
$$

である.ただし $T$ は絶対温度, $N$ は Avogadro 数, $\sigma$ は 分子の直径, $M$ 法分子量である. そして $Z$ は反応する分 子の濃度が $1 \mathrm{~mol} / l$ であるとき, 1 中で毎秒衝突する 分子の数で，ひえ度因子と呼ばれる。 $\mathrm{p}$ 泣立体因子で， 反応が起こるためのエネルギー条件のほかに, 衝突分子 の間になにか特別の配向が必要な場合には，p の值は 1 より小さくなる・多くの実測値はこの説が近似的に正し いことを示している.この理論恃気相反応の久ならず, 溶液中の反応にも適用できるものである.

$(2 \cdot 3)$ 式の両辺の対数をとると

$$
\log k=\log \mathrm{p} Z-\frac{E_{\mathrm{a}}}{2.303 R T}
$$

となる.この式に従う場合, 絶対温度の逆数に対して, その温度の速度定数の対数をプロットすると直線を得る ので，その直線の傾きから実験的活性化エネルギー $E_{\mathrm{a}}$ を求めることができる。あとでみるように, 厳密に取り 扱うと，わずかではあるがひん度因子は温度の影響を受 ける・しかし温度範囲が狭い場合は，ほとえどの反応で ひん度因子は定数である.もっともこれは素反応に関す る場合であって，素反応をいくつか含む条件速度定数の 場合恪各素反応の活性化エネルギーが違うから, 直線に ならない場合があるのは当然である。

反応の実験的活性化エネルギーは二つの異なった温度 での速度定数の值から計算できる.すなわち, 温度 $T_{1}$ ${ }^{\circ} \mathrm{K}, T_{2}{ }^{\circ} \mathrm{K}$ での速度定数がそれぞれ $k_{1}, k_{2}$ テであったと すれば，次の関係式を得る。

$$
\begin{aligned}
& \ln k_{1}=\ln \mathrm{p} Z-\frac{E_{\mathrm{a}}}{R T_{1}} \\
& \ln k_{2}=\ln \mathrm{p} Z-\frac{E_{\mathrm{a}}}{R T_{2}}
\end{aligned}
$$

$(2 \cdot 5)$ 式と $(2 \cdot 6)$ 式から

$$
\ln \frac{k_{1}}{k_{2}}=\frac{E_{\mathrm{a}}}{R}\left(\frac{1}{T_{2}}-\frac{1}{T_{1 \mathbf{3}}}\right)
$$

となる・したがって活性化エネルギーは

$$
E_{\mathrm{a}}=\frac{2.303 R T_{1} T_{2}}{T_{1}-T_{2}} \log \frac{k_{1}}{k_{2}}
$$

となる。

多くの初歩的な書物に, 温度を $10^{\circ} \mathrm{C}$ 上げると反応速 度はおよそ2 倍になるという記述が見受けられる. $25^{\circ} \mathrm{C}$ での反応にあてはめると, 次のような活性化エネルギー に対応する。

$$
\begin{aligned}
E_{\mathrm{a}} & =\frac{2.30 \times 1.99 \mathrm{cal} / \mathrm{mol} \cdot \mathrm{deg} \times 293^{\circ} \mathrm{K} \times 303^{\circ} \mathrm{K}}{10^{\circ} \mathrm{K}} \log 2 \\
& =12.2 \mathrm{kcal} / \mathrm{mol}
\end{aligned}
$$

実験データが全然ない場合には，だいたいのめやすと しては役だつが，活性化エネルギーが $12.2 \mathrm{kcal} / \mathrm{mol}$ に 近くない反応も非常に多くあるから，これにたよりすぎ るの海危険である. $25 \mathrm{kcal} / \mathrm{mol}$ 程度の活性化エネルギ 一を持つ反応では, 温度を $1{ }^{\circ} \mathrm{C}$ まちがえば, 十数パー セントも反応速度定数に違いを生ずることになる。した がって反応速度を用いて定量する場合には反応温度をで きるだけ一定に保つ必要がある.

\section{$2 \cdot 2$ 遷移状態説（絶対反応速度）}

反応物質と活性錯合体との間に平衡が成立しており， ポテンシャルエネルギー面上の最も起こりやすい反応経 路の最高点に位置しているこの活性錯合体が活性化状態 の臨界配置を通過し反応するという考光が，いわゆる遷 移状態説である. 反応に関与する化学種が活性錯合体と は常に平衡にあというのは, 絶対反応速度論の基本的 前提の一つである.

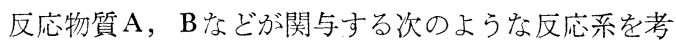
えることにする.

$$
\mathrm{A}+\mathrm{B}+\cdots \longrightarrow \mathrm{M}^{\neq} \longrightarrow \text { 生成物質 }
$$

ここで $\mathrm{M}$ * 活活性錯合体である.反応速度は障壁の 頂点にある活性錯合体の濃度と障壁を通過するひえ度と の積になる、障壁の頂点の活性化状態を表わす長さ $\delta$ の間にある単位体積中の活性錯合体の数を $c^{\neq}$，そこを 横切るときの平均速度を $\bar{v}$ るると, 活性錯合体が障壁 をこえるひえ度は $\bar{v} / \delta$ に等しい。したがって反応速度 は

$$
v=c \neq \frac{\bar{v}}{\delta}
$$

で表わされる・活性化状態を図 $2 \cdot 1$ にポテンシャルエ ネルギー曲線で示してある。

1 分子が 1 自由度内で $\dot{x}$ と $\dot{x}+\mathrm{d} \dot{x}$ の間の速度をも つ確率 $P_{(\dot{x})_{1}}$ は, Boltzmann の分布則に基ゔいて

$$
P_{(\dot{x})_{1}}=\text { 定数 } \times e^{-\frac{1}{2} m \dot{x}^{2} / k T} \mathrm{~d} \dot{x}
$$




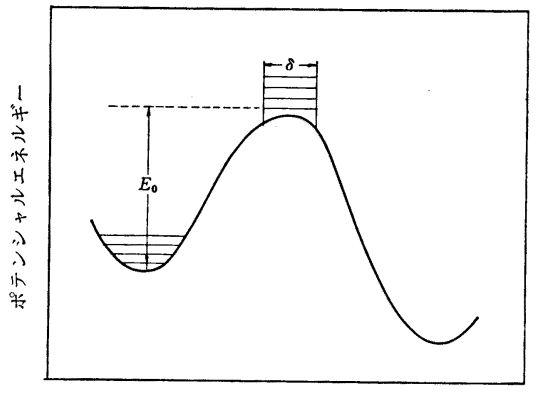

反応座標

図22・1 活性化状態を示した反応のポテンシャルエ ネルギー曲線

で表わすことができる、したがって正の方向の活性錯合 体の平均速度は

$$
\begin{aligned}
\bar{v}=\overline{\dot{x}} & =\frac{\int_{0}^{\infty} e^{-\frac{1}{2} m^{\neq \dot{x}_{2} / k T}} \dot{x} \mathrm{~d} \dot{x}}{\int_{-\infty}^{\infty} e^{-\frac{1}{2} m^{\neq \dot{x}_{2} / k} T} \mathrm{~d} \dot{x}} \\
& =\left(\frac{\boldsymbol{k} T}{2 \pi m^{\neq}}\right)^{\frac{1}{2}} \ldots \ldots \ldots \ldots \ldots \ldots \ldots \ldots \ldots
\end{aligned}
$$

となる・ただし $m$ キ は活性錯合体の有效質量である。し たがって，(2.9)式と $(2 \cdot 11)$ 式から

$$
v=c \neq\left(\frac{\boldsymbol{k} T}{2 \pi m^{\ddagger}}\right)^{1 / 2} \frac{1}{\delta}
$$

一方, 反応速度は反応速度定数を $k$ とすると次の式で 表わされる。

$$
v=k c_{\mathrm{A}} c_{\mathrm{B}} \cdots
$$

$(2 \cdot 12)$ 式と $(2 \cdot 13)$ 式から

$$
k=\frac{c^{\neq}}{c_{\mathrm{A}} c_{\mathrm{B}} \cdots}\left(\frac{\boldsymbol{k} T}{2 \pi m^{\neq}}\right)^{1 / 2} \frac{1}{\delta}
$$

となる、また反応物質と活性錯合体とは平衡状態にある と考えているから，反応物質と活性錯合体との間の平衡 定数 $K_{c} \neq$ は

$$
K_{c} \neq=\frac{c^{\neq}}{c_{\mathrm{A}} c_{\mathrm{B}} \cdots}
$$

と書くことができる。

統計熱力学から導かれる平衡定数の表現を借りれば

$$
K_{c} \neq=\frac{F^{\neq \prime}}{F_{\mathrm{A}} F_{\mathrm{B}} \cdots} e^{-E_{0} / R T}
$$

ただし $F$ はそれぞれの物質の完全な分配関数であり，
$E_{0}$ は反応物質と活性錯合体との 1 モルあたりの零準位 エネルギーの差,すなわち活性化エネルギーに相当する. $(2 \cdot 14)$ 式，(2・15)式，それに $(2 \cdot 16)$ 式から

$$
k=\frac{F^{\neq \prime}}{F_{\mathrm{A}} F_{\mathrm{B}} \cdots}\left(\frac{\boldsymbol{k} T}{2 \pi m^{\ddagger}}\right)^{\frac{1}{2}} \frac{1}{\delta} e^{-E_{0} / R T}
$$

となる、活性錯合体が遷移状態を通るということ活性 錯合体のもつ全振動のうちの一つが並進運動に変わった ことを意味する・そこで今，活性錯合体の完全な分配関 数 $F \neq 1$ の代わりに，並進運動に基づく関数を含まない 新しい関数 $F \neq$ を用いると

$$
F \neq \prime=F \neq \frac{\left(2 \pi m^{\neq} \boldsymbol{k} T\right)^{\frac{1}{2}}}{h} \delta
$$

と表わせるから，これを(2・17)式に代入すると

$$
k=\frac{\boldsymbol{k} T}{h} \frac{F^{\neq}}{F_{\mathrm{A}} F_{\mathrm{B}} \cdots} e^{-E_{0} / R T}
$$

となる・ここまでは，エネルギー障壁をこえるすべての 活性錯合体注反応するという仮定に立ってきたが，すべ て反応するわけではないという可能性を考慮するため, 透過係数 $\kappa$ を導入すると

$$
k=\kappa \frac{\boldsymbol{k} T}{h} \frac{F^{\neq}}{F_{\mathrm{A}} F_{\mathrm{B}} \cdots} e^{-E_{0} / R T}
$$

と表わすことができる・(2·20)式は Eyring の絶対反応 速度式として知られているものである.これによって原 理的には反応物質と活性錯合体の性質を知って速度定数 を計算することができる。

活性錯合体が正規分子とみなしてよい場合には（F⿻/

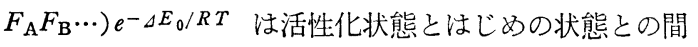
の平衡定数 $K^{\ddagger}$ となる.したがって， $(2 \cdot 20)$ 式は次の ようになる。

$$
k=\kappa \frac{k T}{h} K \neq
$$

定数 $K^{\ddagger}$ は一般の平衡定数と同じように, 熱力学の式 によって, 標準自由エネルギー $\Delta F$ (活性化自由エネル ギー: free energy of activation), 標準エンタルピー变 化 $\Delta H^{\ddagger}$ (活性化エンタルピー : enthalpy of activation), および標準エントロピー変化 $\Delta S$ ま (活性化エントロピー： entropy of activation) と関係づけることができ，(2. 21)式は次のようになる。

$$
k=\kappa \frac{\boldsymbol{k} T}{h} e^{-\Delta F^{\ddagger} / R T}
$$




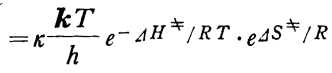

この式からわかるように，反応速度を決定する因子は 活性化エンタルピーではなく, 活性化自由エネルギーで ある、もし単純な Arrhenius の式を用いる場合には, 実 験的活性化エネルギー $E_{\mathrm{a}}$ はある程度温度によって变わ り，(2.2)式の A はエントロピ一項を含むことを忘れて はならない。

次に，一般に活性化エンタルピーは実験的活性化エネ ルギーと少ししか違わないことを示す. (2.21) 式の両辺 の対数をとると

$$
\ln k=\ln \kappa \frac{\boldsymbol{k}}{h}+\ln T+\ln K^{\ddagger}
$$

となり，これを温度 $T$ で微分すると

$$
\begin{aligned}
\frac{\mathrm{d} \ln k}{\mathrm{~d} T} & =\frac{1}{T}+\frac{\mathrm{d} \ln K^{\ddagger}}{\mathrm{d} T} \\
& =\frac{1}{T}+\frac{\Delta H^{\ddagger}}{R T^{2}} \cdots
\end{aligned}
$$

また, Arrhenius の式から

$$
\frac{\mathrm{d} \ln k}{d T}=\frac{E_{\mathrm{a}}}{R T^{2}}
$$

$$
\begin{aligned}
& \text { したがって } \\
& E_{\mathrm{a}}=R T+\Delta H^{\neq}
\end{aligned}
$$

となる・

$(2 \cdot 26)$ 式を $(2 \cdot 22)$ 式に代入すると

$$
k=\kappa \frac{\boldsymbol{k} T}{h} e^{(R T-E \mathrm{a}) / R T_{e} \triangleleft S^{\neq} / R}
$$

$$
=\kappa \frac{e \boldsymbol{k} T}{h} e^{-E \mathrm{a} / R T} e^{-S^{\ddagger} / R}
$$

一般の論交にみられる反応速度の熱力学的変数は（2$27)$ 式の関係にある. $(2 \cdot 3)$ 式と $(2 \cdot 27)$ 式との比較から

$$
\mathrm{p} Z=\kappa \frac{\boldsymbol{k} T}{h} e^{\ominus} S^{\ddagger} / R
$$

である.そして活性化エンタルピーは

$$
\Delta H^{\ddagger}=E_{\mathrm{a}}-R T
$$

によって与えられ， $25^{\circ} \mathrm{C} て ゙ ~ R T$ は $0.59 \mathrm{kcal} / \mathrm{mol}$ 程 度の小さい值であるから，一般に実験的活性化エネルギ 一 $E_{\mathrm{a}}$ と $\Delta H^{\ddagger}$ とはあまり違わないことがわかる。

以上でいわゆる絶対反応速度論についてのごく概略を 述べたが，詳しくは他の成書を参照していただきたい9.。

\section{交献}

1) R. H. Holyer, C. D. Hubbard, S. F. A. Kettle, R. G. Wilkins : Inorg. Chem., 5, 622 (1966).

2) S. Funahashi, M. Tanaka : 未発表.

3) R. G. Pearson, O. A. Gansow : Inorg. Chem., 7, 1373 (1968).

4) P. Ellis, R. G. Wilkins : J. Chem. Soc., 1959, 299.

5) R. Hogg, R. G. Wilkins : ibid., 1962, 341.

6) R. S. Bell, N. Sutin : Inorg. Chem.,1,359(1962).

7) R. Holyer, G. Hubbard, S. Kettle, R. G. Wilkins : ibid., 4, 935 (1965).

8) B. R. Baker, B. D. Mehta : ibid., 4,848(1965).

9) S. Glasstone, K. J. Laidler, H. Eyring : "The Theory of Rate Processes", (1941), (McGrawHill Book Company, Inc., New York). 長谷川繁夫，平井西夫，後藤春雄訳 : “絶対反応 速度論”, 上, 下 (1964), (吉岡書店). 